\title{
The Effects of Multi-year Altitude Training on the Biochemical Function and Specific Aerobic Capacity of the Elite Open Weight Woman Rowers
}

\author{
X. Huang, H. Wu, S.F. Yan \& J.B. Li \\ Capital University of Physical Education and Sports, Beijing, China
}

ABSTRACT: Objective: This study was to discuss the influence of multi-year altitude training on the biochemical function and specific aerobic capacity of the Chinese national elite open weight woman athletes and to explore the law. Method: Organise tracking test of 12 Chinese rowing open weight woman Olympians' function state in the past 3 years' altitude training camp. Result: (1) The lactate threshold power is lower during the altitude training than that on the sea level $(\mathrm{P}<0.01)$; compared with before altitude training camp, the lactate threshold power increased significantly after altitude training camp, $(\mathrm{P}<0.01)$; it was observed, with horizontal comparison of the past 3 times altitude training, that the lactate threshold power increased annually, and increased most in 2008 particularly. (2) During the altitude training camps in the past 3 years, the body weight tended to decrease but there was no significant difference compared with on the sea level. The body fat percentage increased to the highest point in the latter part of the altitude training, while the lean body mass decreased to the lowest point in the same period, and increased again significantly after the altitude training camp $(\mathrm{P}<0.05)$. (3) During the altitude training camp, $6 \mathrm{~km}$ Ergometer performance went down clearly; the best performance appeared in the $4^{\text {th }}$ week of the altitude training camp. (4) With no clear difference in Hct index, for open weight woman athletes, the HB level had a negative correlation with 6km Ergometer performance (Pearson correlation is $-0.952, \mathrm{P}<0.05$ ); The $4^{\text {th }}$ week of the altitude training camp saw the peak $\mathrm{HB}$ value and the best $6 \mathrm{~km}$ Ergometer results. Conclusion: (1) The study of the influence of altitude training on the lactate threshold power indicates that altitude training can significantly improve rowers' aerobic capacity. (2) the environment of altitude led to a faster muscle decomposition, so during the altitude training, the body weight of open weight woman athletes dropped clearly. (3) In this study, after the altitude training, the $\mathrm{Hb}$ level had a negative correlation with $6 \mathrm{~km}$ Ergometer performance and the aerobic capacity came to the highest level in the $4^{\text {th }}$ week after the altitude training camp.

KEYWORD: Olympic Games; multi-year altitude training; rowing; lactate threshold power; aerobic capacity

\section{INTRODUCTION}

Before Beijing Olympic Games, China rowing team trained on altitude during every winters in multithree-years. In the end, they got a gold medal and a silver medal in 2008 Olympic Games. This study was to discuss the influence of multi-year altitude training on the biochemical function and specific aerobic capacity of the Chinese national elite open weight woman athletes and to explore the law.

\section{OBJECTS AND METHODS}

\subsection{Objects}

Table 1 The basic circs of objects

\begin{tabular}{|l|c|c|c|c|}
\hline & $\begin{array}{c}\text { Age } \\
(\text { year})\end{array}$ & $\begin{array}{c}\text { Height } \\
(\mathrm{m})\end{array}$ & $\begin{array}{c}\text { Weight } \\
(\mathrm{Kg})\end{array}$ & $\begin{array}{c}\text { Training } \\
\text { Time (year) }\end{array}$ \\
\hline $\begin{array}{l}\text { Open } \\
\text { weight } \\
\text { female } \\
\text { athletes } \\
(\mathrm{n}=12)\end{array}$ & $22.8 \pm 3.6$ & $1.83 \pm 0.02$ & $77.6 \pm 3.8$ & $7.1 \pm 3.0$ \\
\hline
\end{tabular}

\subsection{Methods}

Organise tracking test of 12 Chinese rowing open weight woman Olympians' function state in the past 
3 years' altitude training camp (Huize in Yunnan, 2150 meters above sea level). The main indexes include Lactate threshold power, Body weight and fat $\%, 6 \mathrm{~km}$ ergometer performance and $\mathrm{Hb}$ level during and after the altitude training.

\section{RESULTS}

\subsection{The lactate threshold power}

The lactate threshold power is lower during the altitude training than that on the sea level $(\mathrm{P}<0.01)$; compared with before altitude training camp, the lactate threshold power increased significantly after altitude training camp, $(\mathrm{P}<0.01)$; it was observed, with horizontal comparison of the past 3 times altitude training, that the lactate threshold power increased annually, and increased most in 2008 particularly.

Table 2. The result of lactate threshold power

\begin{tabular}{|l|l|l|l|l|}
\hline $\begin{array}{l}\text { Test } \\
\text { time }\end{array}$ & $2006^{\prime}$ & 2007 & $2008^{\prime}$ & Average \\
\hline $\begin{array}{l}\text { Before } \\
\text { altitude }\end{array}$ & 262.6 & 267.4 & 276.9 & $269.0 \pm 7.3 \mathbf{a}^{*}, \mathbf{b}, \mathbf{c}^{*}$ \\
\hline $\begin{array}{l}\text { During } \\
\text { Altitude 1 }\end{array}$ & 219.9 & 233.7 & 236.9 & $230.1 \pm 9.0 \mathbf{a}^{*}, \mathbf{d}^{*}$ \\
\hline $\begin{array}{l}\text { During } \\
\text { Altitude 2 }\end{array}$ & 236.7 & 238.5 & 258.4 & $244.5 \pm 12.1 \mathbf{b , \mathbf { e } ^ { * }}$ \\
\hline $\begin{array}{l}\text { After } \\
\text { altitude }\end{array}$ & 274.6 & 279.7 & 292.3 & $282.2 \pm 9.1 \mathbf{c}^{*}, \mathbf{d}^{*}, \mathbf{e}^{*}$ \\
\hline
\end{tabular}

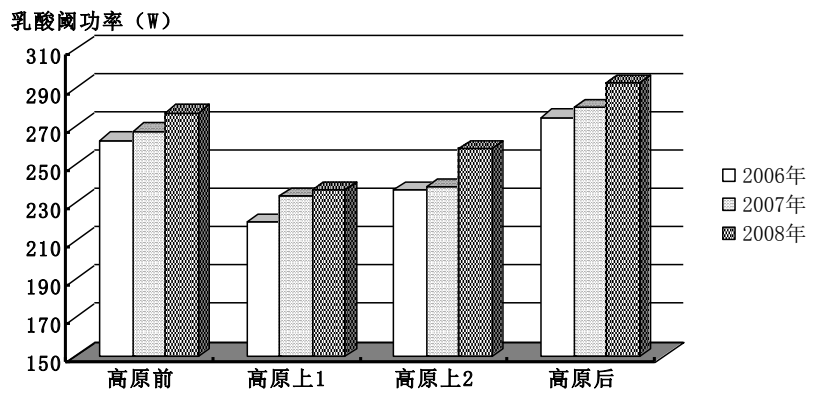

Figure 1. The result of lactate threshold power.

\subsection{The result of the body weight}

During the altitude training camps in the past 3 years, the body weight tended to decrease but there was no significant difference compared with on the sea level. The body fat percentage increased to the highest point in the latter part of the altitude training, while the lean body mass decreased to the lowest point in the same period, and increased again significantly after the altitude training camp $(\mathrm{P}<0.05)$.
Table 3. Results of body weight

\begin{tabular}{|l|c|c|c|c|}
\hline $\begin{array}{l}\text { Body } \\
\text { weight }\end{array}$ & $2006^{\prime}$ & 2007 & $2008^{\prime}$ & average \\
\hline $\begin{array}{l}\text { Before } \\
\text { altitude }\end{array}$ & 76.5 & 76.5 & 76.1 & $76.4 \pm 0.2$ \\
\hline $\begin{array}{l}\text { During } \\
\text { Altitude 1 }\end{array}$ & 75.3 & 75.6 & 75.9 & $75.6 \pm 0.3$ \\
\hline $\begin{array}{l}\text { During } \\
\text { Altitude 2 }\end{array}$ & 75.0 & 75.7 & 75.9 & $75.5 \pm 0.5$ \\
\hline $\begin{array}{l}\text { After } \\
\text { altitude }\end{array}$ & 76.9 & 76.5 & 76.4 & $76.6 \pm 0.3$ \\
\hline
\end{tabular}

Table 4. Results of body fat percentage

\begin{tabular}{|l|l|l|l|l|}
\hline Fat\% & $2006^{\prime}$ & $2007^{\prime}$ & $2008^{\prime}$ & Average \\
\hline $\begin{array}{l}\text { Before } \\
\text { altitude }\end{array}$ & 19.1 & 18.2 & 17.9 & $18.4 \pm 0.6$ \\
\hline $\begin{array}{l}\text { During } \\
\text { Altitude 1 }\end{array}$ & 19.3 & 19.1 & 18.2 & $18.9 \pm 0.6$ \\
\hline $\begin{array}{l}\text { During } \\
\text { Altitude 2 }\end{array}$ & 19.9 & 19.5 & 18.4 & $19.3 \pm 0.8$ \\
\hline $\begin{array}{l}\text { After } \\
\text { altitude }\end{array}$ & 19.5 & 18.0 & 17.8 & $18.5 \pm 0.9$ \\
\hline
\end{tabular}

Table 5. Results of lean body mass

\begin{tabular}{|l|l|l|l|l|}
\hline Lean body mass (kg) & $2006^{\prime}$ & $2007^{\prime}$ & $2008^{\prime}$ & Average \\
\hline $\begin{array}{l}\text { Before } \\
\text { altitude }\end{array}$ & 61.9 & 62.3 & 62.5 & $62.2 \pm 0.3$ \\
\hline $\begin{array}{l}\text { During } \\
\text { Altitude 1 }\end{array}$ & 60.8 & 61.2 & 62.1 & $61.4 \pm 0.7 \mathrm{a}$ \\
\hline $\begin{array}{l}\text { During } \\
\text { Altitude 2 }\end{array}$ & 60.1 & 60.9 & 61.9 & $61.0 \pm 0.9 \mathrm{~b}$ \\
\hline $\begin{array}{l}\text { After } \\
\text { altitude }\end{array}$ & 61.9 & 62.7 & 62.8 & $62.5 \pm 0.5 \mathrm{a}, \mathrm{b}$ \\
\hline
\end{tabular}

\subsection{The result of $6 \mathrm{~km}$ Ergometer performance}

During the altitude training camp, 6km Ergometer performance went down clearly; the best performance appeared in the $4^{\text {th }}$ week of the altitude training camp.

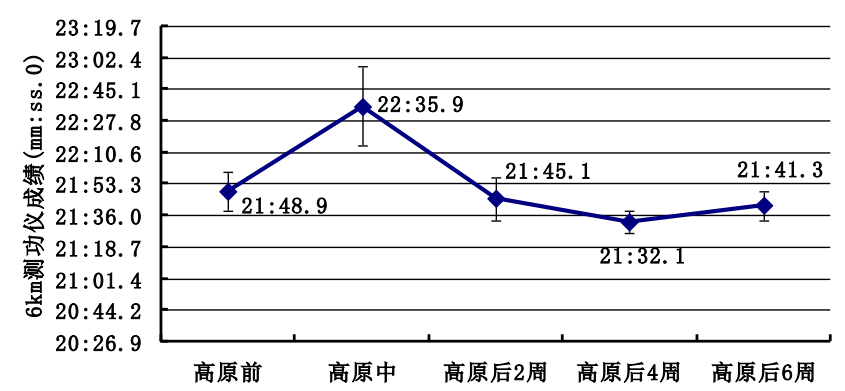

Figure 2. The result of $6 \mathrm{~km}$ Ergometer performance .

\subsection{The correlation of $6 \mathrm{~km}$ Ergometer performance and $\mathrm{HB}$ level}

With no clear difference in Hct index, for open weight woman athletes, the HB level had a negative correlation with $6 \mathrm{~km}$ Ergometer performance (Pearson correlation is $-0.952, \mathrm{P}<0.05$ ); The $4^{\text {th }}$ week of the altitude training camp saw the peak $\mathrm{HB}$ value and the best $6 \mathrm{~km}$ Ergometer results. 


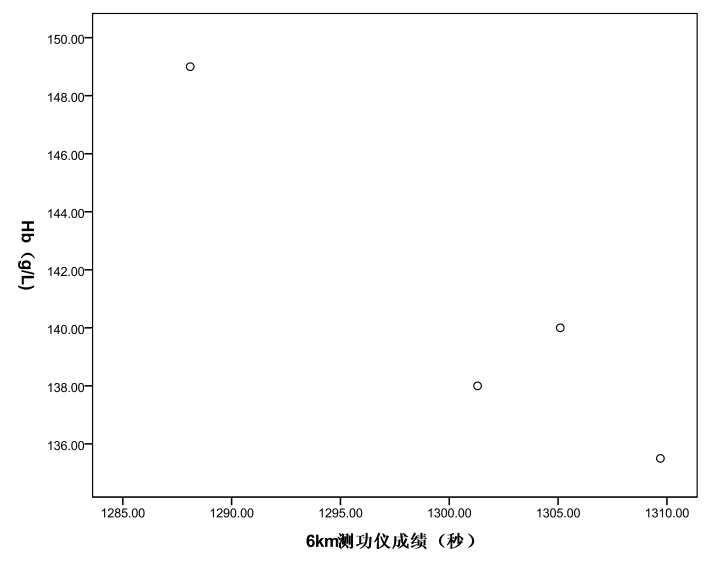

Figure 3. The correlation of $6 \mathrm{~km}$ Ergometer performance and HB level (Pearson correlation is $-0.952, \mathrm{P}<0.05$ )

\section{CONCLUSION}

4.1 The study of the influence of altitude training on the lactate threshold power indicates that altitude training can significantly improve rowers' aerobic capacity.

4.2 The environment of altitude led to a faster muscle decomposition, so during the altitude training, the body weight of open weight woman athletes dropped clearly.

4.3 In this study, after the altitude training, the $\mathrm{Hb}$ level had a negative correlation with $6 \mathrm{~km}$ Ergometer performance and the aerobic capacity came to the highest level in the $4^{\text {th }}$ week after the altitude training camp.

\section{SUGGESTION}

5.1 During the altitude training, the lactate threshold power was lower than that on sea level, and the capacity of lactate tolerance decreased clearly. We should enhance the intensity monitoring during the altitude training, to avoid fatigue phenomenon.

5.2 During altitude training, the female rowers' lean body mass decreased significantly. When on plateau, special nutritional supplements and physical accumulation should be much more concerned about.

\section{REFERENCES}

[1] Galea G, et a1. Hemorrheology of marathon running. Int J Sports Med, 1985, 6: 136-138.

[2] Bull BS, Koepke JA, Simson E, et a1. Procedure for determining packed cell volume by the microhemetocrit method; approved standard-third edition. NCCLS H7-A3. 2000.

[3] Bull BS, Fujimoto K, Klee G, et a1. International Council for Standardization in Hematology (ICSH) recommendations for "Surrogate Reference" method for the packed cell volume. Laboratory Hematology, 2003, 9: 1.

[4] Convertino VA. Heart rate and sweat rate responses associated with exercise-induced hypervolemia. Med Sci Sports Exerc 1983: 15(1): 77-82.

[5] Magnusson B, Hallberg L, Rossander L, et a1. 1ron metabolism and "sports anemia". II. A hematological comparison of elite runners and control subjects. Acta Med Scand 1984; 216(2): 157-164

[6] Sawka. M. N, A. J. Young, P. E. Rock et al. Altitude acclimatization and blood volume: effects of exogenous erythrocyte volume expansion. Appl Physiol,1996, 81: 636-642

[7] Stevens, G.H. J, B. H. Foresman, X. Shi et al. Reduction in LBNP tolerance following prolonged endurance exercise training. Med Sci Sports Exerc. 1992, 24: 1237-1244

[8] Robach. P., M. Dechaux, S Jarrot et a1. Operation EverestIII: role of plasma volume expansion on VO2max during prolonged high-altitude exposure. Appl Physiol 2000, 89: 29-37

[9] Chapman, R. F., J. Stray-Gundersen and B.D. Levine. Individual variation in altitude training. J Appl Physio1. 1998. 85:1448-1455

[10]Lewis, D. M., A. R Bradwell, A.C. Shore et al. Capillary filtrations coefficient and urinary albumin leak at altitude. Eur. J. Clin. Invest. 1997, 27: 64-68

[11]Wolfer E.E., B.M. Groves, G.A. Brollks et a1. Oxygen transport during steady state sub maximal exercise in chrome hypoxia, Appl Physio1. 1991,70:1129-1136 